\title{
Histopathological and molecular studies in patients with goiter and hypercalcitoninemia: reactive or neoplastic C-cell hyperplasia?
}

\author{
Uberta Verga, Stefano Ferrero ${ }^{2}$, Leonardo Vicentini ${ }^{1}$, Tatiana Brambilla ${ }^{2}$, \\ Valentina Cirello, Marina Muzza, Paolo Beck-Peccoz and Laura Fugazzola
}

\author{
Endocrine Unit, Department of Medical Sciences, University of Milan and Fondazione Policlinico IRCCS, Milan, Italy \\ ${ }^{1}$ Endocrine Surgery Unit, Fondazione Policlinico IRCCS, Milan, Italy \\ ${ }^{2}$ Pathology Unit, Department of Medicine, Surgery and Dentistry, University of Milan, Ospedale S Paolo and Fondazione Policlinico \\ IRCCS, Milan, Italy
}

(Requests for offprints should be addressed to L Fugazzola who is now at Institute of Endocrine Sciences, Fondazione Policlinico IRCCS Pad Granelli, Via Francesco Sforza 35, 20122 Milan Italy; Email: I.fugazzola@ policlinico.mi.it)

\begin{abstract}
The cut-off values able to differentiate between reactive or neoplastic C-cell hyperplasia $(\mathrm{CCH})$ or to predict sporadic medullary thyroid cancer (MTC) are still debated both for basal and stimulated calcitonin (bCT and $\mathrm{sCT}$ ). In the present study, the prevalence and the histological patterns of $\mathrm{CCH}$ in 15 patients with multinodular goiter (MNG), bCT $>10 \mathrm{pg} / \mathrm{ml}$ and sCT levels $>50 \mathrm{pg} / \mathrm{ml}$ were studied. As controls, 16 patients with MNG and bCT levels $<10 \mathrm{pg} / \mathrm{ml}$ and 4 patients with familial (FMTC) were included. For each case, calcitonin (CT) immunoreactive cells were counted in 60 consecutive high-power fields $(400 \times)$ and $\mathrm{CCH}$ classified as focal, diffuse, nodular, or neoplastic. RET genetic analyses were performed at the germline and tissue levels in MTC and $\mathrm{CCH}$ cases. In patients with MNG, sCT levels $>50 \mathrm{pg} / \mathrm{ml}$ were associated with $\mathrm{CCH}$ or MTC, being the total number of C-cells/60 fields significantly higher than that found in MNG with normal bCT $(P=0.0008)$ and comparable with that detected in FMTCs. In the group with sCT $>50 \mathrm{pg} / \mathrm{ml}$, the C-cells displayed a neoplastic phenotype. Neither germline nor somatic RET mutations were found. In conclusion, sCT levels $>50 \mathrm{pg} / \mathrm{ml}$ were always associated with $\mathrm{CCH}$, without correlation between $\mathrm{CT}$ levels and the number of $\mathrm{C}$-cells or the final diagnosis. The $\mathrm{C}$-cells had a morphology and distribution pattern similar to those observed in FMTC. Thus, sCT levels $>50 \mathrm{pg} / \mathrm{ml}$ indicate the presence of $\mathrm{CCH}$ with a possible preneoplastic potential, suggesting the opportunity to perform a prophylactic surgical treatment.
\end{abstract}

Endocrine-Related Cancer (2007) 14 393-403

\section{Introduction}

Medullary thyroid cancer (MTC) accounts for 5-10\% of thyroid cancers and occurs in both sporadic and hereditary forms (Sizemore et al. 1977, Schlumberger \& Pacini 2003). Its biological behavior is more aggressive than that reported for the other welldifferentiated thyroid cancers, with a 10-year survival rate of about 70\% (Modigliani et al. 1998, Schlumberger \& Pacini 2003). Indeed, clinical neck lymph node and distant metastases are detected at presentation in $\sim 50-70$ and $15-20 \%$ of patients respectively (Modigliani et al. 1998). Moreover, the primary, and virtually the only, therapeutic approach is the surgical intervention, since other treatments are poorly effective.
Thus, the main goal in MTC management is to diagnose the disease in a preneoplastic condition, corresponding to C-cell hyperplasia $(\mathrm{CCH}) . \mathrm{CCH}$ is defined as an increased number of normal C-cells, more commonly with a diffuse pattern, i.e. 50 or more C-cells in at least one low-power field $(100 \times)$, a number greater than that found in most normal subjects (De Lellis \& Wolfe 1981, Albores-Saavedra \& Krueger 2001) and has been classified as physiologic/reactive or neoplastic (Perry et al. 1996, Matias-Guiu et al. 2004). Reactive CCH has been reported in neonates, the elderly, hyperparathyroidism, Hashimoto's thyroiditis, and follicular thyroid adenomas (Guyetant et al. 1994, Matias-Guiu et al. 2004) and can be defined, according to the growth 
pattern of C-cells, as focal, diffuse, or nodular (Perry et al. 1996, Kaserer et al. 2001). Neoplastic CCH is usually associated with hereditary MTC (familial MTC-, FMTC-, or MEN 2), but some of the authors have supported the idea that it might also be the precursor of sporadic MTC (sMTC) in the absence of germline RET mutations (Perry et al. 1996, Kaserer et al. 1998). According to the definition proposed by Perry et al. (1996), neoplastic CCH is characterized by the presence of large, mildly to moderate atypical, round, polygonal, or spindle-shaped cells with nuclear pleomorphisms (Perry et al. 1996). These cytological alterations would allow the C-cells to differentiate from the follicular cells and, therefore, to diagnose the neoplastic $\mathrm{CCH}$ on hematoxylin and eosin (H\&E) sections, while the reactive type usually would require immunohistochemistry (IHC) for its identification. However, the pathological definition and clinical correlation of reactive and neoplastic $\mathrm{CCH}$ are still unclear (LiVolsi 1997) and some of the authors reported that, morphologically, it is not possible in most cases to distinguish with certainty between neoplastic and reactive $\mathrm{CCH}$ (Hinze et al. 2001, Kaserer et al. 2001).

In hereditary MTC, the finding of RET mutations frequently allows to perform the prophylactic thyroidectomy at the $\mathrm{CCH}$ stage, with a major impact on the prognosis (Eng et al. 1996). Conversely, the diagnosis of sMTC is usually done when the tumor is clinically manifest. However, a significant increase in early diagnoses has followed the introduction of the routine measurement of calcitonin (CT) levels in patients presenting with thyroid nodules. Indeed, many reports have shown than the routine CT measurement has a specificity and sensitivity higher than the fine needle aspiration cytology and leads to the detection of MTC in about $0.4-0.5 \%$ of the patients (Pacini et al. 1994, Rieu et al. 1995, Niccoli et al. 1997, Vierhapper et al. 1997, Ozgen et al. 1999, Hahm et al. 2001, Elisei et al. 2004, Karanikas et al. 2004). The main pitfall related to this screening is the correct interpretation of borderline cases. It is well accepted that when CT levels above the normal range are found in patients with uni- or (UNG or MNG), a pentagastrin (Pg) stimulation test must be performed. In the absence of a CT response to $\mathrm{Pg}$, the diagnosis of MTC can be excluded, while the increases in the CT levels after stimulus are often difficult to be interpreted. In general, a CT response $<50 \mathrm{pg} / \mathrm{ml}$ is considered normal (Wion-Barbot et al. 1997), a response $>50$ and $<100 \mathrm{pg} / \mathrm{ml}$ is a borderline result, while a CT rise of $>100 \mathrm{pg} / \mathrm{ml}$ suggests the diagnosis of MTC and the need for surgical treatment (Niccoli et al. 1997, Scheuba et al. 1999, Iacobone et al. 2002, Elisei et al. 2004). However, no cut-off levels of sCT able to differentiate between reactive and neoplastic $\mathrm{CCH}$ or to predict MTC have been identified (Iacobone et al. 2002, Gibelin et al. 2005).

The aim of the present study was to define the prevalence and the histological patterns of $\mathrm{CCH}$ in patients with nodular thyroid disease and $\mathrm{SCT}$ levels $>50 \mathrm{pg} / \mathrm{ml}$. The data obtained were compared with those from patients with MNG and basal CT levels $<10 \mathrm{pg} / \mathrm{ml}$, and with those from patients with sMTC and hereditary MTC/CCH. For the first time, RET genetic analyses were performed not only at the germline level, but also starting from DNA extracted from $\mathrm{CCH}$.

\section{Materials and methods}

\section{Patients}

In the period comprised between March 2002 and December 2005, 1246 patients referred to our outpatient departments with uni- or (UNG, MNG) were submitted to routine serum CT measurement. In addition, all patients underwent clinical examination, neck ultrasonography and measurement of thyroid hormones, and anti-thyroid autoantibodies. Basal CT (bCT) levels above the normal range (i.e. $>10 \mathrm{pg} / \mathrm{ml}$ ) were found, and confirmed at a second assay, in 32 cases who were thus submitted to Pg test. In all these patients, a familial history of MTC was excluded. Of the 32 patients, 17 had a stimulated CT (sCT) $<50 \mathrm{pg} / \mathrm{ml}$ and were considered normal. These patients had bCT levels ranging $10.5-20 \mathrm{pg} / \mathrm{ml}$ (median 11) and sCT ranging 20-49.2 pg/ml (median 41.1), without correlation between the basal and the stimulated levels of CT. In the remaining 15 patients, who had bCT levels ranging 17-196 pg/ml (median 35) and a sCT $>50 \mathrm{pg} / \mathrm{ml}$, total thyroidectomy was performed due to: a) $\mathrm{sCT}>100 \mathrm{pg} / \mathrm{ml}$ in seven cases (\# 2-5, 11, 12, and 15); b) bCT $>100 \mathrm{pg} / \mathrm{ml}$ and cytology positive for MTC in two cases (\# 13 and 14); and c) tracheal deviation/compression and/or esthetic reasons in the remaining six cases (Table 1). The 15 patients submitted to total thyroidectomy and included in the present study (\# 1-15; eight M, seven F; age range 33-73 years, mean 56.8 years, median 59 years) had a normal thyroid function with negative antithyroid autoantibodies in 13 and positive in 2 patients (\# 4 and 12; (Table 1)). The renal function was normal in all, thus excluding that the elevated basal and SCT levels could be due to a renal failure, as reported in the literature (Niccoli et al. 1995, Kotzmann et al. 1999). Moreover, other causes of abnormal CT levels, such as endocrine malignant tumors and hypergastrinemia, were excluded. All patients were operated in the 
Table 1 Clinical, biochemical, and histopathological data of the 15 patients with nodular goiter and preoperative basal and stimulated CT (sCT) levels $>10 \mathrm{pg} / \mathrm{ml}$ and $>50 \mathrm{pg} / \mathrm{ml}$ respectively

\begin{tabular}{|c|c|c|c|c|c|c|c|c|}
\hline \multirow[b]{2}{*}{ Pts \# } & \multirow[b]{2}{*}{$\begin{array}{c}\text { Age, } \\
\text { gender }\end{array}$} & \multirow{2}{*}{$\begin{array}{c}\text { CT pre-Tx } \\
\text { basal/peak } \\
(\mathrm{pg} / \mathrm{ml})\end{array}$} & \multirow[b]{2}{*}{ Cytology } & \multicolumn{5}{|c|}{ Histology ${ }^{a}$} \\
\hline & & & & Goiter & Cancer & PTNM & $\begin{array}{c}\mathrm{CCH} \text { at initial } \\
\text { diagnosis }\end{array}$ & $\begin{array}{c}\mathrm{CCH} \text { at } \\
\text { re-evaluation }\end{array}$ \\
\hline 1 & $47, \mathrm{~F}$ & $17 / 61$ & Neg & MNG & - & & + & + \\
\hline 2 & $50, \mathrm{M}$ & $35 / 333$ & $\mathrm{Nd}$ & MNG & - & & - & + \\
\hline 3 & $73, \mathrm{~F}$ & $33 / 112$ & Neg & MNG & - & & + & + \\
\hline 4 & $65, \mathrm{M}$ & $30 / 588$ & $\mathrm{Neg}$ & MNG/CLT & - & & - & + \\
\hline 5 & $49, \mathrm{M}$ & $25 / 219$ & $\mathrm{Neg}$ & MNG/CLT & - & & + & + \\
\hline 6 & $51, M$ & $51 / \mathrm{nd}$ & $\mathrm{Nd}$ & MNG & - & & + & + \\
\hline 7 & $33, F$ & $33 / \mathrm{nd}$ & $\mathrm{Nd}$ & UNG & - & & - & + \\
\hline 8 & $37, \mathrm{M}$ & $17 / 62$ & Neg & UNG & - & & - & + \\
\hline 9 & $62, M$ & $31 / 97$ & $\mathrm{Neg}$ & MNG/CLT & PTC & T3Nx (13 mm) & - & + \\
\hline 10 & $59, F$ & $59 /$ nd & $\mathrm{Nd}$ & MNG/CLT & PTC & T1N0 (10 mm) & - & + \\
\hline 11 & $70, \mathrm{M}$ & $47 / 390$ & Neg & MNG & PTC & $\mathrm{T} 1 \mathrm{mNx}(4,1 \mathrm{~mm})$ & + & + \\
\hline 12 & $58, F$ & $39 / 553$ & $\mathrm{Nd}$ & MNG/CLT & MTC & $\mathrm{T} 1 \mathrm{Nx}(5 \mathrm{~mm})$ & + & + \\
\hline 13 & $65, F$ & $182 / n d$ & MTC & MNG & MTC & T1N0 (14 mm) & - & + \\
\hline 14 & $63, \mathrm{~F}$ & $196 /$ nd & MTC & MNG & MTC & T1N0 (13 mm) & - & + \\
\hline 15 & $71, M$ & $81 / 1783$ & $\mathrm{Nd}$ & UNG & MTC & T1N0 (12 mm) & + & + \\
\hline
\end{tabular}

Pts, patients; Tx, thyroidectomy; CT, calcitonin (basal and peak after pentagastrin test); nd, not done; MNG, multinodular goiter; UNG, uninodular goiter; CLT, chronic lymphocytic thyroiditis; PTC, papillary thyroid cancer; MTC, medullary thyroid cancer; CCH, Ccells hyperplasia. Cancers were staged according to the last TNM staging system, ICD-O C73 (AJCC 2002). In parentheses, the primary tumors are reported in $\mathrm{mm}$.

ammunohistochemistry for CT was done in all the cases, with the exception of \# 4 at initial diagnosis, and in all the cases at re-evaluation.

Endocrine Surgery Department and specimens were examined by the same Department of Pathology. The initial histological diagnoses were performed by means of routine staining and, in all cases but \# 4, by specific anti-CT (IHC; Table 1). In particular, in eight patients, the diagnosis of benign nodular goiter was performed, associated with thyroiditis in five cases, while in three patients, benign nodules were associated with incidental papillary thyroid cancers (PTCs). Finally, medullary thyroid cancer was diagnosed in four patients. Cancers were staged according to the last TNM staging system, ICD-O C73 (AJCC 2002). CCH was diagnosed in four MNG (\# 1, 3, 5, and 6), one PTC ( \# 11) and two MTC (\# 12 and 15). It is worth to note that CCH was not diagnosed in \# 4, which was analyzed only by routine staining, and in other seven cases studied by specific IHC and entire thyroid blocking.

After surgery, all patients showed undetectable basal and, in some cases, $\mathrm{Pg}-\mathrm{sCT}$ levels, confirming the thyroid production of CT.

All patients were screened and followed up in the Endocrine Sciences Department and gave informed consent to the study.

\section{Controls}

Data were compared with a control group of 16 patients matched for gender and age (\# C1-C16; $6 \mathrm{M}$,
$10 \mathrm{~F}$; age range 29-78 years, mean 57.4 years, median 56.5 years), operated for MNG or UNG with normal bCT (i.e. $<10 \mathrm{pg} / \mathrm{ml}$ ), negative anti-thyroid autoantibodies in 11 out of 13 patients, studied and operated in the same departments (Table 2). Furthermore, four patients affected with FMTC submitted to prophylactic thyroidectomy, following $R E T$-positive genetic analyses, were considered as controls for neoplastic $\mathrm{CCH}$. Indeed, familial $\mathrm{CCH}$ is a preneoplastic lesion and considered as the carcinoma in situ of the thyroid gland parafollicular cells (LiVolsi 1997, Kaserer et al. 2001, Matias-Guiu et al. 2004). The first case (\# FMTC1) is a 6-year-old child with a mild response to Pg test (bCT $17 \mathrm{pg} / \mathrm{ml}$, sCT $61 \mathrm{pg} / \mathrm{ml}$ ), with a histological diagnosis of $\mathrm{CCH}$ and normal CT levels at the post-surgical follow-up. This child harbored a recently described RET complex mutation, K666N/insS (Cordella et al. 2006). The second case (\# FMTC2) is a 33-year-old man with high presurgical bCT levels $(98 \mathrm{pg} / \mathrm{ml})$ and a multicentric MTC at histology (pT1mN0), harboring the RET mutation C634F. The third and fourth cases (\# FMTC3 and FMTC4) are father and son (50 and 22 years) with the RET mutation C618S, with high bCT levels (2152 and $342 \mathrm{pg} / \mathrm{ml}$ ) and MTC associated with $\mathrm{CCH}$ at histology (pT3mNO and pT1N0). 
Table 2 Clinical, biochemical, and molecular data of the controls: 4 patients with familial medullary thyroid cancer (FMTC) and 16 patients with uni- or multinodular goiter (MNG) and preoperative CT levels $<10 \mathrm{pg} / \mathrm{ml}$

\begin{tabular}{lccc}
\hline Pts \# & Age/gender & $\begin{array}{c}\text { CT pre-Tx basal/ } \\
\text { peak (pg/ml) }\end{array}$ & RET \\
\hline FMTC1 & $6 / \mathrm{M}$ & $17 / 61$ & $\mathrm{~K} 666 \mathrm{~N} / \mathrm{insS}$ \\
FMTC2 & $33 / \mathrm{M}$ & $98 / \mathrm{nd}$ & $\mathrm{C} 634 \mathrm{~F}$ \\
FMTC3 & $50 / \mathrm{M}$ & $2152 / \mathrm{nd}$ & $\mathrm{C} 618 \mathrm{~S}$ \\
FMTC4 & $22 / \mathrm{M}$ & $342 / \mathrm{nd}$ & $\mathrm{C} 618 \mathrm{~S}$ \\
C1 & $51 / \mathrm{F}$ & 4 & $\mathrm{Nd}$ \\
C2 & $73 / \mathrm{M}$ & 5.6 & $\mathrm{Nd}$ \\
C3 & $52 / \mathrm{F}$ & 2.1 & $\mathrm{Nd}$ \\
C4 & $52 / \mathrm{F}$ & 2 & $\mathrm{Nd}$ \\
C5 & $30 / \mathrm{F}$ & 3.4 & $\mathrm{Nd}$ \\
C6 & $55 / \mathrm{M}$ & 7.8 & $\mathrm{Nd}$ \\
C7 & $62 / \mathrm{F}$ & 1.7 & $\mathrm{Nd}$ \\
C8 & $78 / \mathrm{M}$ & 2.3 & $\mathrm{Nd}$ \\
C9 & $66 / \mathrm{F}$ & 5.4 & $\mathrm{Nd}$ \\
C10 & $52 / \mathrm{F}$ & 8.1 & $\mathrm{Nd}$ \\
C11 & $48 / \mathrm{F}$ & 1.8 & $\mathrm{Nd}$ \\
C12 & $59 / \mathrm{F}$ & $<2$ & $\mathrm{Nd}$ \\
C13 & $44 / \mathrm{F}$ & 2.8 & $\mathrm{Nd}$ \\
C14 & $68 / \mathrm{M}$ & 5.9 & $\mathrm{Nd}$ \\
C15 & $71 / \mathrm{M}$ & 4.3 & $\mathrm{Nd}$ \\
C16 & $58 / \mathrm{M}$ & 6.5 & $\mathrm{Nd}$ \\
\hline
\end{tabular}

\section{Methods}

\section{Biochemical investigations}

CT serum levels were measured by a commercially available two-site chemiluminescence immunometric assay (ILMA; Nichols Institute Diagnostics, Nijmegen, The Netherlands). The ILMA recognizes the mature monomeric form of CT. Two mouse monoclonal antibodies directed against two different epitopes (Grauer et al. 1998, Skinner et al. 2005) are used. The sensitivity of the assay is $0.2 \mathrm{pg} / \mathrm{ml}$. The intra- and inter-assay coefficients of variation are $<4.5$ and $<11.1 \%$ respectively. All samples were evaluated in duplicate. Serum thyroid-stimulating hormone, FT4, FT3, Tg-Ab, and TPO-Ab were measured using the AutoDELFIA technique (Perkin Elmer-Life Sciences, Wallac Oy, Turku, Finland), being normal values of $0.26-4.2 \mathrm{mU} / \mathrm{l}$, 9-20 pmol/l, 3.8-8 pmol/l, and $<35 \mathrm{U} / \mathrm{l}$ respectively. All patients were submitted to ultrasonography of the neck. Pg test was performed with an indwelling catheter and CT was measured at $-10,0,2,5$, and 10 min after an i.v. bolus of $0.5 \mu \mathrm{g} / \mathrm{kg} \mathrm{Pg}$ (Peptavlon Injection BP; Cambridge Laboratories, Cambridge, UK).

\section{Immunohistochemical studies}

For each of the 35 cases included in the study (15 patients and 20 controls), six paraffin blocks (three from the left and three from the right lobes corresponding to upper, intermediate, and lower zones) were selected according to the following major criteria: a) good morphology and b) well preservation of follicular structures (extensive fibrotic or hemorrhagic areas were excluded). From each paraffin block, additional $5 \mu \mathrm{m}$ sections were obtained and tested for CT reactivity by means of a specific rabbit polyclonal antibody, using an immunoperoxidase technique. Briefly, the sections were dewaxed, rehydrated in xylene and alcohol, and subjected to antigen retrieval by means of three 6-min microwave cycles in sodium citrate ( $\mathrm{pH}$ 6.0); endogenous peroxidase was blocked by means of incubation with $3 \%$ hydrogen peroxide in deionized water for $10 \mathrm{~min}$. They were then incubated for $30 \mathrm{~min}$ at $4{ }^{\circ} \mathrm{C}$ with a rabbit polyclonal antibody specific for human $\mathrm{CT}$ (Biocare Medical, Carino Diablo Suite 300, Walnut Creek, CA, USA) at 1:400 dilution. The antigen-bound antibody was detected using an anti-rabbit peroxidaseconjugated secondary antibody (Envision-HRP rabbitDAKO, Carpinteria, CA, USA). After being stained with 3,3'-diamino-benzidine and counterstained with $\mathrm{H} \& \mathrm{E}$, the samples were dehydrated with alcohol and xylene, and slides were prepared for light microscopy examination. Control sections were obtained by omitting the primary antibody or using an unrelated rabbit polyclonal antibody.

In the first step, all H\&E-stained slides were re-screened for carcinomas or 'neoplastic' $\mathrm{CCH}$, according to the definition proposed by Perry et al. (1996). In the second step, CT immunoreactivity in C-cells was evaluated at low magnification $(100 \times)$ in order to detect single positive cells or 'hot spots' of clustered cells. CCH was defined as an increased number of normal appearing C-cells (at least more than 50 C-cells per low-power field; Albores-Saavedra et al. 1988, Perry et al. 1996). In the third step, all CT immunoreactive cells were counted starting by hot spots (if detectable) in 60 consecutive high-power fields $(400 \times)$. As far as the CT-positive cells distributed around a MTC focus is concerned, the tumor was excluded from the count and used as an internal positive control. With this time-consuming and laborious procedure, the entire slide or a large representative area of the sample under study was evaluated. According to the growth pattern of C-cells, $\mathrm{CCH}$ was morphologically defined as focal, diffuse, nodular, or 'neoplastic'. Focal $\mathrm{CCH}$ was defined by a segmental proliferation pattern of C-cells, diffuse $\mathrm{CCH}$ was diagnosed when C-cells were located all around a thyroid follicle, while nodular $\mathrm{CCH}$ consisted in the complete obliteration of the follicular lumen by hyperplastic C-cells (Kaserer et al. 2001, Matias-Guiu et al. 2004). As far as the definition of 
neoplastic $\mathrm{CCH}$ is concerned, we followed the definition given by Perry et al. defining it as the presence of large, mildly to moderately atypical, intrafollicular cells resembling those of MTC with immunoreactivity for CT.

All the slides were independently read by two pathologists (S F and T B).

\section{Genetic studies}

After approval of the Ethic Committee of the Institution and informed consent of the patients, genetic studies were performed in the 11 cases with MNG and elevated CT levels and in the four SMTC cases. The core of the tumors as well as the areas containing the highest number of C-cells were microdissected from paraffin blocks ( $5 \mu \mathrm{m}$ slices). DNA was then extracted by standard methods after xylene deparaffinization. Amplifications of exons 10, 11 , and $13-16$ of the RET gene, which have been reported to be mutated at the somatic level in SMTC (reviewed in Arighi et al. 2005), were performed using primers flanking each exon. The four patients diagnosed with MTC at histology were also submitted to the genetic analysis starting from leukocyte DNA and PCR amplifying RET exons 10, 11, and 13-15. All samples were subjected to 5 -min denaturation at $98{ }^{\circ} \mathrm{C}$, followed by 30 three-step cycles (appropriate annealing temperature for $45 \mathrm{~s}, 72{ }^{\circ} \mathrm{C}$ for $30 \mathrm{~s}$, and $94{ }^{\circ} \mathrm{C}$ for $30 \mathrm{~s}$ ), $72{ }^{\circ} \mathrm{C}$ for $10 \mathrm{~min}$ in a TouchDown Thermal Cycler (Hybaid, Middlesex, UK). PCR products were directly sequenced after the removal of unincorporated dNTPs and primers by a GFX PCR DNA purification kit (Amersham Pharmacia Biotech). An aliquot of $3-10 \mathrm{ng} / 100 \mathrm{bp}$ purified DNA and 3.2 pmol of either the forward or reverse primer were used in standard cycle sequencing reactions with $\mathrm{ABI}$ PRISM Big Dye terminators and run on an ABI PRISM 310 Genetic Analyzer (PE Applied Biosystems, Foster City, CA, USA). The cycle-sequencing conditions consisted of 25 cycles at $96^{\circ} \mathrm{C}$ for $30 \mathrm{~s}, 50{ }^{\circ} \mathrm{C}$ for $15 \mathrm{~s}$, and $60{ }^{\circ} \mathrm{C}$ for $4 \mathrm{~min}$. One sequence read from each direction across the entire coding region, including intron-exon boundaries, was obtained for each patient.

\section{Results}

The original histological diagnoses were confirmed in all cases by the two pathologists involved in the present study. In particular, the diagnoses of papillary microcarcinoma in cases \# 9-11 and of MTC in patients \# 12-15 were confirmed (Table 1). Thus, the incidence of MTC in the present series was of $0.32 \%$ (4 out of 1246 patients with thyroid nodule(s) submitted to the routine measurement of $\mathrm{CT}$ ). $\mathrm{CCH}$ was demonstrated in all cases, including \# 2, 7-10, 13, and 14 that were negative for $\mathrm{CCH}$ at the original histological and IHC investigations (Table 1), probably due to the lower number of sections examined. Indeed, after accurate analysis of 60 consecutive high-power fields $(400 \times)$ obtained from the six paraffin blocks (three from the left and three from the right lobe corresponding to upper, intermediate, and lower zones), a number of C-cells higher than 50 per low-power field and in many cases higher than six cells/follicle were always found, thus satisfying all diagnostic criteria for CCH (Williams et al. 1987, Perry et al. 1996, Albores-Saavedra et al. 1988). CCH was found not only in the upper and intermediate zones, where it is usually predominantly or exclusively located (Scheuba et al. 2000, Kaserer et al. 2002), but also in the lower zones. In particular, the eight patients with $\mathrm{MNG} / \mathrm{UNG}$ and the three cases with associated PTC showed a high number of C-cells in all the sections examined, with a total number ranging 195-2571 (median 1050; Table 3). The total number of C-cells/60 fields in these patients with presurgical $\mathrm{bCT}>10 \mathrm{pg} / \mathrm{ml}$ and $\mathrm{sCT}>50 \mathrm{pg} / \mathrm{ml}$ did not differ from that detected in patients with sMTC (85-2696, median 411.5) and FMTC (592-1695, median 1343), but was significantly higher than that found in the 16 control patients who underwent surgery for MNG or UNG with bCT $<10 \mathrm{pg} / \mathrm{ml}$ (0-167, median 59; $P<0.0008$ ) (Table 3). Indeed, in these 16 age- and sex-matched MNG patients (Table 2), CT immunoreactive cells displayed a normal localization (parafollicular area), morphology (spindle), distribution pattern of the elements (almost always isolated), and number $(<50$ per low-power field and never exceeding six per follicle). Neither basal nor sCT levels showed significant correlation with the number of C-cells or the final diagnosis. Patients \# 1 and 8 had bCT and sCT levels (17 out of 61 and 17 out of $62 \mathrm{pg} / \mathrm{ml}$ respectively) comparable with those found in a FMTC patient (\# FMTC1) with $\mathrm{CCH}$ at histology (17 out of $61 \mathrm{pg} / \mathrm{ml}$ ). Moreover, patients \# 4 and 12, with comparable basal and sCT values (30 out of 588 and 39 out of $553 \mathrm{pg} / \mathrm{ml}$ respectively) and anti-TPO autoantibodies at low titer ( 88 and $65 \mathrm{U} / 1$, normal value $<35$ ), had a diffuse and nodular $\mathrm{CCH}$ (\# 4), and a microMTC (\# 12) respectively. In the group of patients with elevated presurgical bCT and sCT levels, excluding the four MTC cases, C-cells were not only increased in number, but also showed a different morphology and localization compared with the normal parafollicular cells. Indeed, these cells showed a focal and/or diffuse distribution (more than six immunoreactive cells per follicle) with a strong 
Table 3 Total number of C-cells detected in the thyroid samples of the different groups of patients

\begin{tabular}{|c|c|c|c|c|c|c|c|c|}
\hline & $\begin{array}{c}\text { Pts \# MNG + } \\
\text { sCT> } \\
50 \mathrm{pg} / \mathrm{ml}\end{array}$ & $\begin{array}{l}\text { Total no. } \\
\text { of C-cells }\end{array}$ & $\begin{array}{c}\text { Pts \# MNG + } \\
\text { bCT }< \\
10 \mathrm{pg} / \mathrm{ml}\end{array}$ & $\begin{array}{l}\text { Total no. } \\
\text { of C-cells }\end{array}$ & Pts \# sMTC & $\begin{array}{l}\text { Total no. } \\
\text { of C-cells }\end{array}$ & Pts \# FMTC & $\begin{array}{l}\text { Total no. } \\
\text { of C-cells }\end{array}$ \\
\hline & 1 & 1050 & $\mathrm{C} 1$ & 59 & 12 & 332 & FMTC1 & 1695 \\
\hline & 2 & 1102 & $\mathrm{C} 2$ & 59 & 13 & 2696 & FMTC2 & 1654 \\
\hline & 3 & 454 & $\mathrm{C} 3$ & 0 & 14 & 491 & FMTC3 & 1032 \\
\hline & 4 & 847 & $\mathrm{C} 4$ & 62 & 15 & 85 & FMTC4 & 592 \\
\hline & 5 & 2115 & $\mathrm{C} 5$ & 92 & & & & \\
\hline & 6 & 2571 & C6 & 37 & & & & \\
\hline & 7 & 327 & $\mathrm{C7}$ & 167 & & & & \\
\hline & 8 & 715 & $\mathrm{C} 8$ & 31 & & & & \\
\hline & 9 & 1940 & $\mathrm{C9}$ & 144 & & & & \\
\hline & 10 & 195 & C10 & 39 & & & & \\
\hline & 11 & 1527 & $\mathrm{C} 11$ & 138 & & & & \\
\hline & & & C12 & 0 & & & & \\
\hline & & & $\mathrm{C} 13$ & 133 & & & & \\
\hline & & & $\mathrm{C} 14$ & 71 & & & & \\
\hline & & & $\mathrm{C} 15$ & 111 & & & & \\
\hline & & & C16 & 28 & & & & \\
\hline Range & & $195-2571^{*}$ & & $0-167^{\star}$ & & 85-2696 & & $592-1695$ \\
\hline Median & & 1050 & & 59 & & 411.5 & & 1343 \\
\hline
\end{tabular}

${ }^{\star} P=0.0008$ by $t$-test (group 'patients MNG $+\mathrm{sCT}>50 \mathrm{pg} / \mathrm{ml}$ ' versus group 'patients $\mathrm{MNG}+\mathrm{bCT}<10 \mathrm{pg} / \mathrm{ml}$ '). Pts, patients; sCT, stimulated calcitonin; bCT, basal calcitonin; no., number; MNG, multinodular goiter; SMTC, sporadic medullary thyroid cancer; FMTC, familial medullary thyroid cancer.

cytoplasmic immunoreactivity, but often they lost the marginal follicular disposition and displayed a nodular intrafollicular distribution highly resembling the features of the neoplastic $\mathrm{CCH}$ found in the FMTC cases used as positive controls (Fig. 1). Moreover, the cells tended to loose their fuse or dendritic aspect, assuming a round or polygonal shape and in some patients more than $100 \mathrm{CT}$ immunoreactive cells were detectable in two high-power fields, with a nodular distribution and cytological features strongly comparable with those of the invasive component of microMTCs (Fig. 2). In contrast with the definition of Perry et al. stating that neoplastic $\mathrm{CCH}$ can be diagnosed at H\&E sections (Perry et al. 1996, Matias-Guiu et al. 2004), in the case \# 12 the final diagnosis of microMTC with neoplastic $\mathrm{CCH}$ was not done at $\mathrm{H} \& \mathrm{E}$ sections, even after its re-examination, while it was achieved after IHC analysis, which allowed to identify malignant features.

$\mathrm{CCH}$ was bilateral in 8 out of 11 cases of MNG, associated or not with PTC, and in 3 out of 4 cases of sMTC. Typically, a higher number of C-cells were found adjacent to benign thyroid nodules or PTCs (\# 5, 6, 9, and 11; Fig. 3). No peritumoral inflammation was detected around PTCs. As far as the sMTCs is concerned, in all cases CT positive cells were adjacent, peritumoral, homolateral, but also controlateral to the MTC (\# 13; Fig. 3). The morphology of the C-cells was highly comparable with that observed for the MTC used as an internal control and the pattern was usually nodular, similar to that observed in FMTC cases (Fig. 1 panel D). Finally, in accordance with the literature (Guyetant et al. 1997, Scheuba et al. 2000), no correlations between the number of C-cells and the gender or the age of the patients were found.

\section{Genetic studies}

The RET genetic analyses performed at the genomic level in patients \# 12-15 did not reveal germline mutations, thus leading to the diagnosis of sMTC. Moreover, in these tumoral tissues, no RET somatic mutations were identified. Interestingly, for the first time in the present study, the genetic analysis was also done starting from the DNA extracted from the regions containing the highest concentrations of C-cells in all the 15 patients with $\mathrm{CCH}$, but no RET mutations were detected.

\section{Discussion}

In MTC management, the early diagnosis has been shown to be associated with a significantly better outcome (Pacini et al. 1994, Rieu et al. 1995, Niccoli et al. 1997, Vierhapper et al. 1997, Ozgen et al. 1999, Hahm et al. 2001, Elisei et al. 2004, Karanikas et al. 2004). RET gene analysis, particularly in hereditary forms, and routine CT measurement, in sporadic tumors, allow to identify MTC at a very early stage, 


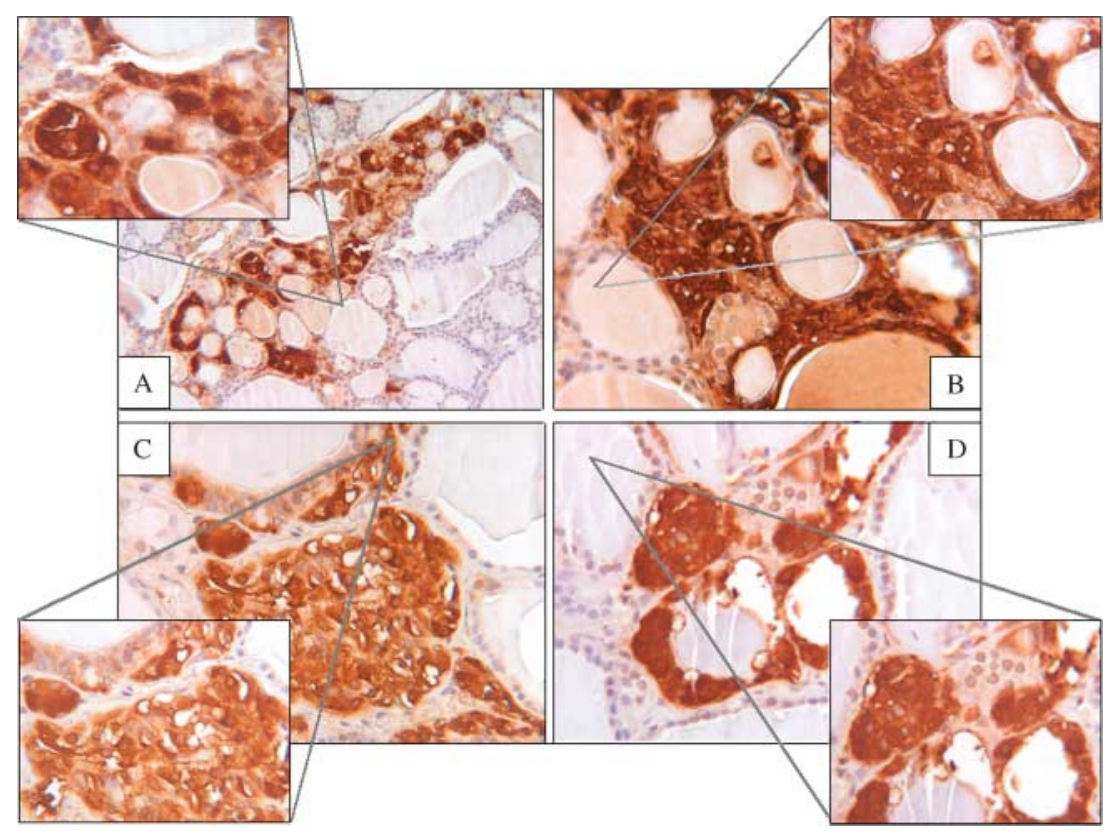

Figure 1 Exemplificative cases of $\mathrm{C}$-cell hyperplasia $(\mathrm{CCH})$ at immunohistochemistry $(200 \times)$, according to the criteria of the World Health Organization (American Joint Committee on Cancer 2002): (A) diffuse CCH constituted by round to polygonal C-cells in a patient with multinodular goiter (\# 5); (B) nodular CCH in a multinodular goiter with incidental papillary thyroid cancer (\# 11); (C) and (D) nodular $\mathrm{CCH}$ in one patient with familial medullary thyroid cancer (\# FMTC1 and FMTC2), considered as a positive control for neoplastic CCH. In all the cases, an inset picture $(400 \times)$ is reported, showing the more detailed morphology. Note that all samples are highly comparable in terms of the C-cells number and distribution.

with the main goal to diagnose the disease in a preneoplastic condition, corresponding to $\mathrm{CCH}$. $\mathrm{CCH}$ has been classified as neoplastic or physiologic/ reactive, being the malignant potential of this second type of $\mathrm{CCH}$ not yet fully demonstrated (Perry et al. 1996, Matias-Guiu et al. 2004).

The present study confirms the diagnostic usefulness of the routine measurement of serum CT in patients with nodular goiter. Indeed, 4 out of $1246(0.32 \%)$ tested subjects were submitted to thyroidectomy due to $\mathrm{bCT}$ or $\mathrm{sCT}>100 \mathrm{pg} / \mathrm{ml}$ and were found to be affected with MTC, being this prevalence comparable with that reported in the literature (Rieu et al. 1995, Elisei et al. 2004, Karanikas et al. 2004). In these cases, an early diagnosis was obtained and all patients are in complete remission after thyroidectomy. The cost-effectiveness of the routine measurement of $\mathrm{CT}$ in thyroid nodules is still debated. Presently, the cost of a single CT measurement varies between 20 US dollars (\$, present study), $\$ 35$ (Austria, Vierhapper et al. 1997) and $\$ 100$ (USA, Castro \& Gharib 2005). It follows that the cost for detecting one MTC approximately varies between $\$ 4000$ and $\$ 20000$. These costs are not prohibitive when balanced against the complex and expensive follow-up that is generally adopted in a patient operated at a later stage, including imaging to localize the residual or recurrent disease and the possible re-operation. These considerations have also been made by several researchers from different countries (Dunn 1994, Sheppard 1995, Vierhapper et al. 1997, Elisei et al. 2004). Moreover, present results indicate that the costs can be lower if $\mathrm{CCH}$ with neoplastic features is included, leading the overall prevalence of the lesions identified by CT measurement to rise from 0.32 to $1.2 \%$. In this series of patients with nodular thyroid disease, and in accordance to data from the literature (Scheuba et al. 1999, Scheuba et al. 2000, Kaserer et al. 2002), bCT levels $>10$ pg/ml (range

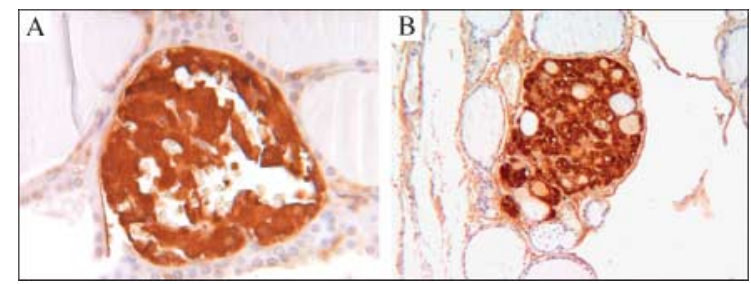

Figure 2 Exemplificative cases of nodular C-cell hyperplasia (CCH) at immunohistochemistry, according to the criteria of the World Health Organization (American Joint Committee on Cancer 2002): (A) nodular CCH surrounding a sporadic MTC (\# 12; $400 \times$ ) and (B) nodular $\mathrm{CCH}$ in a multinodular goiter (\# 2; $200 \times$ ). Note that the samples are highly similar as far as morphology and distribution pattern are concerned. 


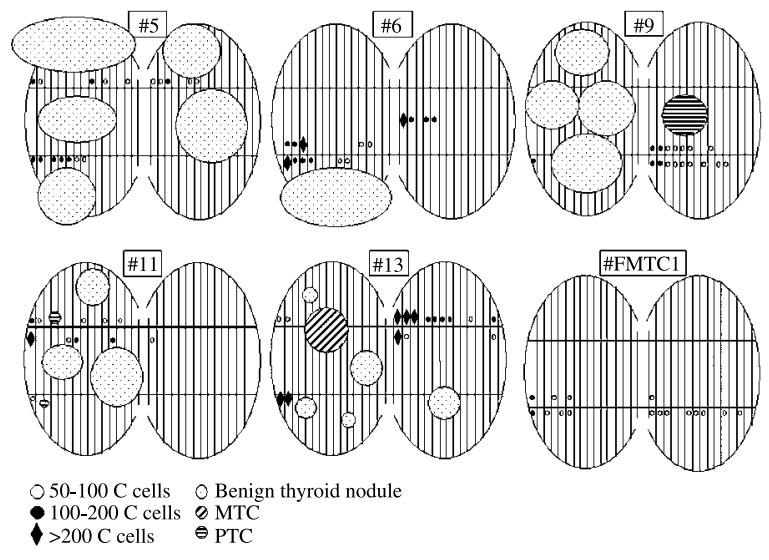

Figure 3 The number and distribution of C-cell hyperplasia in six exemplificative cases with benign thyroid nodule(s) (\# 5, 6, and 11), papillary thyroid cancer (\# 9), sporadic medullary thyroid cancer (\# 13), and familial medullary thyroid cancer (\# FMTC1). For each case, six paraffin blocks (three from the left and three from the right lobes corresponding to upper, intermediate and lower zones) were selected. For each block, a $5 \mu \mathrm{m}$ section was cut and immunostained. All CT immunoreactive cells were counted in 60 consecutive high-power fields $(400 \times)$. Each vertical bar corresponds to four high-power fields. Only C-cell counts higher than $50 \times 4$ high-power fields are reported.

$17-196 \mathrm{pg} / \mathrm{ml}$ ) and $\mathrm{sCT}$ levels $>50 \mathrm{pg} / \mathrm{ml}$ (range $61-1783 \mathrm{pg} / \mathrm{ml}$ ) were always associated with $\mathrm{CCH}$ when accurate blocking was done. As demonstrated in the present series and previous reports (Guyetant et al. 1997), the partial examination of the thyroid glands may lead to non-representative material, according to the heterogeneity of C-cell distribution. Moreover, the present findings highlight the importance of an expert pathologist and suggest the routine use of specific IHC for the examination of cases with elevated preoperative CT levels. The analysis of 60 consecutive high-power fields $(400 \times)$ showed in the 11 patients with presurgical bCT levels $>10 \mathrm{pg} / \mathrm{ml}$ and sCT levels $>50 \mathrm{pg} / \mathrm{ml}$ and a final diagnosis of nodular goiter or PTC, a total number of C-cells/60 fields comparable with that detected in patients with sMTC and FMTC. Conversely, the total number of C-cells was significantly higher than that found in the 16 age- and sexmatched controls who underwent surgery for MNG or UNG with CT levels $<10 \mathrm{pg} / \mathrm{ml}(P=0.0008)$. The range and mean number of C-cells is higher than that reported in the literature for a similar population (range 195-2571, mean 1167 vs range 105-606, mean 296 reported by Kaserer et al. 1998), possibly due to the high number of sections examined in the present study. Accordingly, $\mathrm{CCH}$ was also detected in the inferior third of the two lobes, at variance with what was found in normal thyroids at autopsy (Guyetant et al. 1997) and in previous reports on CCH (Scheuba et al. 2000, Kaserer et al. 2002).

In accordance with the literature (Kaserer et al. 1998), no correlation between CT levels and the number of C-cells or the final diagnosis was found, being bCT and sCT comparable in patients harboring at histology either benign thyroid pathology or MTC. However, the number of C-cells was highly specific in differentiating between MNG patients with $\mathrm{bCT}>10 \mathrm{pg} / \mathrm{ml}$ responsive to $\mathrm{Pg}$ and patients with $\mathrm{bCT}<10 \mathrm{pg} / \mathrm{ml}$. With the aim to verify whether a minimum bCT exists above which patients stimulated $>50 \mathrm{pg} / \mathrm{ml}$, the bCT and sCT levels found in the group of 17 patients, with $\mathrm{bCT}>10 \mathrm{pg} / \mathrm{ml}$ but $\mathrm{sCT}<50 \mathrm{pg} / \mathrm{ml}$ and thus considered normal, were examined. In this group, the bCT range was $10.5-20 \mathrm{pg} / \mathrm{ml}$ (median 11) being significantly different $(P=0.007$ by $t$-test $)$ from that found in the group with sCT $>50 \mathrm{pg} / \mathrm{ml} \quad(17-196 \mathrm{pg} / \mathrm{ml}$, median 35). However, even if an overlap exists between the bCT levels of the two groups, it could be assumed that, at least in the present series, bCT levels above $20 \mathrm{pg} / \mathrm{ml}$ are predicted to lead to a $\mathrm{Pg}-\mathrm{sCT}>50 \mathrm{pg} / \mathrm{ml}$.

The malignant potential of $\mathrm{CCH}$ found in the present series of patients is not easy to prove. Indeed, the criteria to identify the lower limit of microinvasive MTC and the upper limit of CCH/C-cell neoplasia are still debated (LiVolsi 1997). The definition originally given by (Perry et al. 1996) considers that neoplastic $\mathrm{CCH}$, differently from reactive $\mathrm{CCH}$, is associated with cytological atypias, and it is therefore recognizable on routine H\&E sections. However, as reported by other authors (Krueger et al. 2000, Hinze et al. 2001, Kaserer et al. 2001), the morphology of both reactive and neoplastic C-cells can be extremely variable and the differential diagnosis between them is not possible in most cases. Accordingly, in the present series, cytological atypias have been frequently observed in patients with sCT levels $>50 \mathrm{pg} / \mathrm{ml}$. Moreover, the cytological features and patterns of $\mathrm{CCH}$ in benign nodular disease and PTCs with sCT $>50 \mathrm{pg} / \mathrm{ml}$ were similar to those found in CCH of FMTC cases and commonly classified as preneoplastic (Fig. 1) or in $\mathrm{CCH}$ surrounding the sMTC cases (Fig. 2). On the contrary, in the 16 control patients with bCT $<$ $10 \mathrm{pg} / \mathrm{ml}$, the C-cells showed normal morphology, distribution, and localization.

To further underline the overlap between reactive $\mathrm{CCH}$, neoplastic $\mathrm{CCH}$ and even microinvasive MTC, it is worth of mention that in the present series a microMTC was lost at H\&E examination and was differentiated from the surrounding $\mathrm{CCH}$ only by the immunohistochemical identification of some 
malignant features. Indeed, in the absence of lymph node metastases, even the diagnosis of sMTC can be difficult, since in many cases either stromal amyloid, calcifications, or necrosis and other features of malignancy can be absent (Krueger et al. 2000, Kaserer et al. 2001). Another criterion to define the neoplastic $\mathrm{CCH}$ is the presence of bilaterality, which is reported to be absent in reactive CCH (Perry et al. 1996). In the present series, bilaterality was found in 8 out of 11 MNG with sCT $>50 \mathrm{pg} / \mathrm{ml}$ cases, in 3 out of $4 \mathrm{sMTC}$ cases and in all FMTC cases. This finding further underlines the neoplastic features of the $\mathrm{CCH}$ found in the present series. Thus, present data suggest that $\mathrm{SCT}$ levels $>50 \mathrm{pg} / \mathrm{ml}$ are associated with a $\mathrm{CCH}$ of uncertain preneoplastic potential, but with many histological features typical of neoplastic $\mathrm{CCH}$ and clearly different from the control group. The only way to definitely distinguish between reactive or neoplastic $\mathrm{CCH}$ would be the presence or absence of a $R E T$ mutation. For these reasons, in the present series, RET was analyzed for the first time at the tissue level in $\mathrm{CCH}$ areas, unfortunately with negative results. Some different hypotheses can be formulated to explain the lack of mutations in both $\mathrm{CCH}$ and sMTC: a) low number of C-cells in paraffin samples; (b) real absence of RET involvement, accordingly with the prevalence of $40-50 \%$ of somatic gene mutations in sMTC (Arighi et al. 2005); (c) possible unrecognized mutations in different exons of RET; and (d) other genetic event leading to $\mathrm{CCH}$, with the RET mutation occurring as a second hit to give the full neoplastic tranformation. Nonetheless, the present results strengthen the hypothesis (Perry et al. 1996, Kaserer et al. 1998) that $\mathrm{CCH}$ might also be the precursor of sMTC in the absence of RET mutations. Finally, the present study confirms the previous observation (Perry et al. 1996, Matias-Guiu et al. 2004) of the localization of the $\mathrm{CCH}$ adjacent and homolateral to benign or PTC nodules. The basis of this phenomenon could reside in a transforming event possibly affecting a group of adjacent cells, even if different in origin. Other hypotheses include the overexpression in thyroid cancers of paracrine growth factors influencing the surrounding $\mathrm{C}$-cells or, alternatively, the overexpression in hyperplastic C-cells of a growth factor favoring the hyperplastic and/or neoplastic transformation in the adjacent follicular cells (Guyetant et al. 1994). In this respect, it is worth to note the high incidence of PTC found in the present series ( 3 out of 15, 20\%). This percentage lies indeed at the upper limit of the range reported for incidental cancers in goiters (5-20\%; Thompson et al. 1978, Nasir et al. 2000).
In conclusion, the present study confirms the diagnostic usefulness of the routine measurement of serum CT in nodular goiter patients. In this series of patients with nodular thyroid disease, sCT levels $>50 \mathrm{pg} / \mathrm{ml}$ were always associated with $\mathrm{CCH}$, without differences in the levels of sCT between patients with $\mathrm{CCH}$ alone or with MTC. By a high-power field magnification $(400 \times)$, the number of C-cells was not different among patients with $\mathrm{CCH}$, sMTC, or FMTC, but was significantly higher than that found in the control patients with MNG and normal bCT. The C-cells found in these patients showed a morphology and distribution pattern similar to those observed in preneoplastic $\mathrm{CCH}$ of familial MTC, satisfying the criteria usually employed to define neoplastic $\mathrm{CCH}$. Thus, sCT levels $>50 \mathrm{pg} / \mathrm{ml}$ indicate the presence of $\mathrm{CCH}$ with a possible preneoplastic potential, indicating the need for a prophylactic surgical treatment.

\section{Acknowledgements}

The authors thank Patrizia Doi for immunohistochemical preparations. The authors declare that there is no conflict of interest that would prejudice the impartiality of this scientific work.

\section{References}

Albores-Saavedra A \& Krueger JE 2001 C-cell hyperplasia and medullary thyroid microcarcinoma. Endocrine Pathology 12 365-367.

Albores-Saavedra A, Monforte H, Nadji M \& Morales AR 1988 C-cell hyperplasia in thyroid tissue adjacent to follicular cell tumors. Human Pathology 19 795-799.

American Joint Committee on Cancer 2002 TNM classification of malignant tumours. In AJCC Cancer Staging Handbook, edn 6, Ch 8, pp 89-98. Eds. FL Greene et al. New York: Verlag.

Arighi E, Borrello MG \& Sariola H 2005 RET tyrosine kinase signaling in development and cancer. Cytokine and Growth Factor Reviews 16 441-467.

Castro MR \& Gharib H 2005 Continuing controversies in the management of thyroid nodules. Annals of Internal Medicine 142 926-931.

Cordella D, Muzza M, Alberti L, Colombo P, Travaglini P, Beck-Peccoz P, Fugazzola L \& Persani L 2006 An in-frame complex germline mutation in the juxtamembrane intracellular domain causing RET activation in familial medullary thyroid carcinoma. Endocrine-Related Cancer 13 945-953.

De Lellis RA \& Wolfe HA 1981 The pathobiology of the human calcitonin (C)-cell: a review. Journal of Clinical Endocrinology and Metabolism 16 25-52. 
Dunn JT 1994 When is a thyroid nodule a sporadic medullary carcinoma? Journal of Clinical Endocrinology and Metabolism 78 824-825.

Elisei R, Bottici V, Luchetti F, Di Coscio G, Romei C, Grasso L, Miccoli P, Iacconi P, Basolo F, Pinchera A et al. 2004 Impact of routine measurement of serum calcitonin on the diagnosis and outcome of medullary thyroid cancer: experience in 10864 patients with nodular thyroid disease. Journal of Clinical Endocrinology and Metabolism 89 163-168.

Eng C, Clayton D, Schuffenecker I, Lenoir G, Cote G, Gagel RF, van Amstel HK, Lips CJ, Nishisho I, Takai SI et al. 1996 The relationship between specific RET proto-oncogene mutations and disease phenotype in multiple endocrine neoplasia type 2 . International RET mutation consortium analysis. JAMA 276 1575-1579.

Gibelin H, Essique D, Jones C, Levillain P, Marechaud R \& Kraimps JL 2005 Increased calcitonin level in thyroid nodules without medullary carcinoma. British Journal of Surgery 92 574-578.

Grauer A, Raue F \& Ziegler R 1998 Clinical usefulness of a new chemiluminescent two-site immunoassay for human calcitonin. Experimental and Clinical Endocrinology and Diabetes 106 353-356.

Guyetant S, Wion-Barbot N, Rousselet MC, Franc B, Bigorgne JC \& Saint-Andre JP 1994 C-cell hyperplasia associated with chronic lymphocytic thyroiditis: a retrospective quantitative study of 112 cases. Human Pathology 25 514-521.

Guyetant S, Rousselet MC, Durigon M, Chappard D, Franc B, Guerin O \& Saint-Andrè JP 1997 Sex-related C cell hyperplasia in the normal human thyroid: a quantitative autopsy study. Journal of Clinical Endocrinology and Metabolism 82 42-47.

Hahm JR, Lee MS, Min YK, Kim KW, Nam SJ, Yang JH \& Chung JH 2001 Routine measurement of serum calcitonin is useful for early detection of medullary thyroid carcinoma in patients with nodular thyroid diseases. Thyroid 11 73-80.

Hinze R, Gimm O, Brauckhoff M, Schneyer U, Dralle H \& Holzhausen HJ 2001 Physiological and neoplastic C-cell hyperplasia of the thyroid. Morphologically and biologically distinct entities? Der Pathologe 22 259-265.

Iacobone M, Niccoli-Sire P, Sebag F, de Micco C \& Henry JF 2002 Can sporadic medullary thyroid carcinoma be biochemically predicted? Prospective analysis of 66 operated patients with elevated serum calcitonin levels World Journal of Surgery 26 886-890.

Karanikas G, Moameni A, Poetzi C, Zettinig G, Kaserer K, Bieglmayer C, Niederle B, Dudczak R \& Pirich C 2004 Frequency and relevance of elevated calcitonin levels in patients with neoplastic and nonneoplastic thyroid disease and in healhty subjects. Journal of Clinical Endocrinology and Metabolism 89 3515-3519.

Kaserer K, Scheuba C, Neuhold N, Weinhäusel A, Vierhapper H, Haas OA \& Niederle B 1998 C-cell hyperplasia and medullary thyroid carcinoma in patients routinely screened for serum calcitonin. American Journal of Surgical Pathology 22 722-728.

Kaserer K, Scheuba C, Neuhold N, Weinhausel A, Haas OA, Vierhapper H \& Niederle B 2001 Sporadic versus familial medullary thyroid microcarcinoma. American Journal of Surgical Pathology 25 1245-1251.

Kaserer K, Scheuba C, Neuhold N, Weinhausel A, Vierhapper H \& Niederle B 2002 Recommendations for reporting $\mathrm{C}$ cell pathology of the thyroid. Wiener Klinische Wochenschrift 114 274-278.

Kotzmann H, Schmidt A, Scheuba C, Kaserer K, Watschinger B, Soregi G, Niederle B \& Vierhapper H 1999 Basal calcitonin levels and the response to pentagastrin stimulation in patients after kidney transplantation or on chronic hemodialysis as indicators of medullary carcinoma. Thyroid 9 943-947.

Krueger JE, Maitra A \& Albores-Saavedra J 2000 Inherited medullary microcarcinoma of the thyroid: a study of 11 cases. American Journal of Surgical Pathology 24 853-858.

LiVolsi VA 1997 C cell hyperplasia/neoplasia (Editorial). Journal of Clinical Endocrinology and Metabolism 82 39-41.

Matias-Guiu X, DeLellis R, Moley JF, Gagel RF, Albores-Saavedra J, Bussolati G, Kaserer K, Williams ED \& Baloch Z 2004 Tumors of the thyroid: medullary thyroid carcinoma. In World Health Organization Classification of Tumours. Tumours of Endocrine Organs, Eds RA De Lellis, RV Lloyd, PU Heitz \& C Eng. Lyon: IARC press.

Modigliani E, Cohen R, Campos JM, Conte-Devolx B, Maes B, Boneu A, Schlumberger M, Bigorgne JC, Dumontier P, Leclerc J et al. 1998 Prognostic factors for survival and for biochemical cure in medullary thyroid carcinoma: results in 899 patients. Clinical Endocrinology 48 265-273.

Nasir A, Chaudhry AZ, Gillespie J \& Kaiser HE 2000 Papillary microcarcinoma of the thyroid: a clinicopathologic and prognostic review. In Vivo 14 367-376.

Niccoli P, Brunet P, Roubicek C, Roux F, Baudin E \& ConteDevolx B 1995 Abnormal calcitonin basal levels and pentagastrin response in patients with chronic renal failure on maintenance hemodialysis. European Journal of Endocrinology 132 75-81.

Niccoli P, Wion-Barbot N, Caron P, Henry JF, de Micco C, Saint André JP, Bigorgne JC, Modigliani E \& Conte-Devolx B 1997 Interest of routine measurement of serum calcitonin: study in a large series of thyroidectomized patients. The French Medullary Study Group. Journal of Clinical Endocrinology and Metabolism 82 338-341.

Ozgen AG, Hamulu F, Bayraktar F, Yilmaz C, Tuzun M, Yetkin E, Tuncyurek M \& Kabalak T 1999 Evaluation of routine basal serum calcitonin measurement for early 
diagnosis of medullary thyroid carcinoma in seven hundred seventy-three patients with nodular goiter. Thyroid 9 579-582.

Pacini F, Fontanelli M, Fugazzola L, Elisei R, Romei C, Di Coscio G, Miccoli P \& Pinchera A 1994 Routine measurement of serum calcitonin in nodular thyroid diseases allows the preoperative diagnosis of unsuspected sporadic medullary thyroid carcinoma. Journal of Clinical Endocrinology and Metabolism 78 867-871.

Perry A, Molberg K \& Albores-Saavedra J 1996 Physiologic versus neoplastic $\mathrm{C}$-cell hyperplasia of the thyroid. Cancer 77 750-756.

Rieu M, Lame MC, Richard A, Lissak B, Sambort B, VuongNgoc P, Berrod JL \& Fombeur JP 1995 Prevalence of sporadic medullary thyroid carcinoma: the importance of routine measurement of serum calcitonin in the diagnostic evaluation of thyroid nodules. Clinical Endocrinology $\mathbf{4 2}$ 453-460.

Scheuba C, Kaserer K, Weinhausl A, Pandev R, Kaider A, Passler C, Prager G, Vierhapper H, Haas OA \& Niederle B 1999 Is medullary thyroid cancer predictable? A prospective study of 86 patients with abnormal pentagastrin test Surgery 126 1089-1096.

Scheuba C, Kaserer K, Lotzmann H, Bieglmayer C, Niederle B \& Vierhapper H 2000 Prevalence of C-cell hyperplasia in patients with normal basal and pentagastrin-stimulated calcitonin. Thyroid 10 413-416.

Schlumberger M \& Pacini F 2003 Medullary thyroid carcinoma. In Thyroid Tumors. edn 2, Ch 5, pp 305-335. Paris: Editions Nucléon.
Sheppard MC 1995 Should serum calcitonin be measured routinely in all patients with nodular thyroid disease? Clinical Endocrinology 42 451-452.

Sizemore GW, Carney JA \& Heath H III 1977 Epidemiology of medullary carcinoma of the thyroid gland: a 5 year experience (1971-1976). Surgical Clinics of North America 57 633-645.

Skinner MA, Moley JA, Dilley WG, Ozwar K, DeBenedetti MK \& Wells SA Jr 2005 Prophylactic thyroidectomy in multiple endocrine neoplasia type 2A. New England Journal of Medicine 353 1105-1113.

Thompson NW, Nishiyama RH \& Harness JK 1978 Thyroid carcinoma: current controversies. Current Problems in Surgery 15 1-15.

Vierhapper H, Raber W, Bieglamayer C, Kasere K, Weinhäusl A \& Niederle B 1997 Routine measurement of plasma calcitonin in nodular thyroid diseases. Journal of Clinical Endocrinology and Metabolism 82 1589-1593.

Williams ED, Ponder BJ \& Craig RK 1987 Immunohistochemical study of calcitonin gene-related peptide in human medullary carcinoma and $\mathrm{C}$ cell hyperplasia. Clinical Endocrinology 27 107-114.

Wion-Barbot N, Schuffenecker I, Niccoli P, Conte-Devolx B, Locomte P, Houdent C, Bigorgne JC \& Modigliani E 1997 Results of the calcitonin stimulation test in normal volunteers compared with genetically unaffected members of MEN2A and familial medullary thyroid carcinoma families. Annales d'Endocrinologie $\mathbf{5 8}$ 302-308. 